\title{
Biotelemetry informing management: case studies exploring successful integration of biotelemetry data into fisheries and habitat management.
}

\begin{tabular}{|c|c|}
\hline Journal: & Canadian Journal of Fisheries and Aquatic Sciences \\
\hline Manuscript ID & cjfas-2017-0530.R1 \\
\hline Manuscript Type: & Perspective \\
\hline $\begin{array}{r}\text { Date Submitted by the } \\
\text { Author: }\end{array}$ & 21-May-2018 \\
\hline Complete List of Authors: & $\begin{array}{l}\text { Brooks, Jill L.; Carleton University Faculty of Science, Biology } \\
\text { Chapman, Jacqueline; Carleton University, Biology } \\
\text { Barkley, Amanda; University of Windsor, Biology } \\
\text { Kessel, Steven; John G Shedd Aquarium, Daniel P. Haerther Center for } \\
\text { Conservation and Research } \\
\text { Hussey, Nigel; University of Windsor, GLIER } \\
\text { Hinch, Scott; University of British Columbia, Department of Forest and } \\
\text { Conservation Sciences } \\
\text { Patterson, David; Department of Fisheries and Oceans } \\
\text { Hedges, Kevin; Fisheries and Oceans Canada, } \\
\text { Cooke, Steven; Carleton University Department of Biology, ; Carleton } \\
\text { University } \\
\text { Fisk, Aaron; University of Windsor, Great Lakes Institute for } \\
\text { Environmental Research } \\
\text { Gruber, Samuel; University of Miami } \\
\text { Nguyen, Vivian M.; Carleton University, Department of Biology }\end{array}$ \\
\hline Keyword: & $\begin{array}{l}\text { knowledge mobilization, Biotelemetry, science communication, } \\
\text { knowledge integration }\end{array}$ \\
\hline $\begin{array}{r}\text { Is the invited manuscript for } \\
\text { consideration in a Special } \\
\text { Issue? : }\end{array}$ & Oceans Tracking Network \\
\hline
\end{tabular}

\section{SCHOLARONE" Manuscripts}




\section{Biotelemetry informing management: case studies exploring successful integration of biotelemetry data into fisheries and habitat management.}

J.L. Brooks ${ }^{1 *}$, J.M. Chapman ${ }^{1}$, A.N. Barkley², S.T. Kessel ${ }^{2,3,8}$, N.E. Hussey², S.G. Hinch ${ }^{4}$, D.A. Patterson ${ }^{5}$, K.J. Hedges ${ }^{6}$, S.J. Cooke ${ }^{1}$, A.T. Fisk ${ }^{7}$, S. H. Gruber ${ }^{8}$, and V.M. Nguyen ${ }^{1,9}$

${ }^{1}$ Fish Ecology and Conservation Physiology Lab, Department of Biology, Carleton University, Ottawa, ON, Canada

${ }^{2}$ University of Windsor - Biological Sciences, 401 Sunset Avenue, Windsor, Ontario. N9B 3P4, Canada.

${ }^{3}$ Daniel P. Haerther Center for Conservation and Research, John G. Shedd Aquarium, 1200 South Lake Shore Drive, Chicago IL 60605, USA.

${ }^{4}$ Pacific Salmon Ecology and Conservation Laboratory, Department of Forest and Conservation Sciences, University of British Columbia, Vancouver, BC, V6T 1Z4, Canada.

${ }^{5}$ Fisheries and Oceans Canada, Cooperative Resource Management Institute, School of Resource and Environmental Management, Simon Fraser University, Burnaby, BC, Canada, V5A 1 S6

${ }^{6}$ Fisheries and Oceans Canada, 501 University Crescent, Winnipeg, Manitoba. R3T 2N6

${ }^{7}$ Great Lakes Institute for Environmental Research, University of Windsor, 401 Sunset Avenue, Windsor, ON, Canada N9B 3P4

${ }^{8}$ Bimini Biological Field Station Foundation, South Bimini, Bahamas.

${ }^{9}$ Office of the Chief Scientist, Natural Resources Canada, Ottawa, ON, Canada

*Corresponding author: Brooks, Jill L.jillbrooks85@,gmail.com, +1-613-600-5895

Chapman, Jacqueline M. jacqchapman@gmail.com

Barkley, Amanda N. barkleya@uwindsor.ca 
Kessel, Steven T. skessel@sheddaquarium.org

Hussey, Nigel E.nehussey@uwindsor.ca

Hinch, Scott G. scott.hinch@ubc.ca

Patterson, David A. david.patterson@dfo-mpo.gc.ca

Hedges, Kevin J. Kevin.Hedges@dfo-mpo.gc.ca

Cooke, Steven J. Steven_Cooke@,carleton.ca

Fisk, Aaron T. afisk@uwindsor.ca

Gruber, Samuel H. sgruber@rsmas.miami.edu

Nguyen, Vivian M. vivian.m.n@gmail.com

\section{Abstract}

Biotelemetry data have been successfully incorporated into aspects of fishery and fish habitat management, however, the processes of knowledge mobilization are rarely published in peer- 
reviewed literature but are valuable and of interest to conservation scientists. Here, we explore case examples from the Ocean Tracking Network (OTN), including Pacific salmon (Oncorhynchus spp.) in BC, Canada, Greenland halibut (Reinhardtius hippoglossoides) in Cumberland Sound, Canada, and lemon sharks (Negaprion brevirostris) in Florida, USA to document key processes for science-integration. Typical recommendations documented in the literature (e.g., co-production of knowledge, transdisciplinary methodologies, applied research questions) were recorded to have had successful fisheries management integration, although we documented some exceptions. In each case, it was early, active and ongoing communication outside of traditional science communication and the visual evidence of fish movement that were critical in engaging all parties with a vested interest. Networks offer forums for knowledge sharing on lessons learned and development of skills to engage in active communication. Greater investments and attention to develop these skills are needed to foster positive and active relationships that can impart real change in management and conservation.

\section{Introduction}

Biotelemetry technology allows researchers to study the links between physiological, environmental, and geographical factors and the movement of wild fish in marine and freshwater realms (Hussey et al. 2015). The ecological information generated by biotelemetry has the potential to change the landscape of fisheries and habitat management relative to traditional fisheries assessment techniques (e.g. mark recapture). Thus far, data generated 
using biotelemetry have been successfully incorporated into several aspects of fishery and fish habitat management, including the delineation of aquatic protected areas, definition of discreet management or stock units, estimation of fisheries induced post release mortality rates, and determining how environmental factors influence fish movements and mortality to inform adaptive management strategies (reviewed in Cooke et al. 2016; Crossin et al. 2017). However, there are also cases where management-relevant biotelemetry data have failed to be incorporated into fisheries management and policy (Young, et al. 2013, Nguyen et al. accepted).

There is growing interest in improving the integration of science into decision making and policy development (Eden 2010; Cook et al. 2013; Cvitanovic et al. 2016; Ogburn et al. 2017). Typically, scientists are advised to collaborate and co-design studies with knowledge users, engage stakeholders and the public, improve and increase science communication, and develop relationships with knowledge users to develop trust and improve accessibility to their research (e.g., Fazey et al. 2012; Nguyen et al. 2016; Young et al. 2016). Often, these recommendations are anecdotal and represent an ideal approach that is difficult to fulfill due to the geographic distribution or diversity of stakeholders (number of different stakeholders with different viewpoints and interests), vulnerability of the research species, or political conflicts among the parties involved. Rarely have the steps or events (i.e. process) and contextual factors that led to successful research integration been documented (Fisk et al. 2017). As biotelemetry is still considered a relatively "new" tool in the world of fisheries management, the varying degrees and experiences to which biotelemetry data have been integrated into decision making makes it an interesting model for exploring the processes by which science is integrated into natural resource management (Young et al. 2013, MacGowen et al. 2016). 
Using case studies that emerged from the Ocean Tracking Network (OTN), we explore the factors and processes that have led to the successful incorporation of biotelemetry data into fisheries management. The Network provides a forum for informal discussions among researchers about lessons learned, as the iterative processes surrounding science integration are rarely published in scientific papers. Understanding and capturing this "process information" is integral to deriving lessons learned for future applications of biotelemetry data as well as other innovative tools. Through OTN's network of researchers, we gained access to the largely undocumented 'behind the scenes' integration process for three case studies that have had varying levels of success in the application of biotelemetry data in fisheries management: 1) Lemon sharks (Negaprion brevirostris) off the coast of Florida, USA; 2) Greenland halibut (Reinhardtius hippoglossoides) in Cumberland Sound, Nunavut, Canada; 3) Pacific salmon (Oncorhynchus spp.) of the Fraser River, British Columbia (B.C.), Canada. We selected these case studies because of the range of management issues and knowledge mobilization challenges. In this article, we compare communication and partner/stakeholder engagement methods used in these studies that led to the successful or partially successful integration of biotelemetry-derived science into management, and how these compare to traditional avenues or barriers of knowledge mobilization. We then discuss the challenges and complexities that were unique to each study, highlight the major process that facilitated the integration of biotelemetry data, and provide recommendations to users of biotelemetry that currently hold or aim to produce management-relevant data.

\section{Case Study 1: Lemon sharks in Florida.}

Shark fisheries in the coastal waters of Florida, USA, contribute an estimated $\$ 900,000$ USD to total fisheries landed values for the state (FWC, Commercial Fisheries Landings Summaries 2015). Commercial fisheries in Florida are managed federally by the 
National Marine Fisheries Service (NMFS) branch of the National Oceanic and Atmospheric Administration (NOAA), and statewide by the Florida Fish and Wildlife Conservation Commission (FWC). The FWC jurisdiction typically covers any fishing conducted within three miles $(<4.8 \mathrm{Km})$ of eastern Florida shoreline, while fishing that occurs 3-20 miles (4.8$32.2 \mathrm{Km}$ ) offshore is managed by the NMFS.

The lemon shark is a large coastal shark found on both sides of the Atlantic Ocean and in the eastern Pacific Ocean that is targeted by both commercial and recreational fisheries (Compagno 1984; Carlson 2012; Shiffman \& Hammershlag, 2014). The lemon shark is a long lived, slow growing species with low reproductive output, making it vulnerable to overfishing therefore it is listed as near threatened by the International Union for Conservation of Nature (IUCN) throughout its range (Brooks et al. 2016; Reyier et al. 2014; IUCN 2017).

In 2001, recreational divers reported the unusual presence of aggregations of large lemon sharks on natural and artificial reefs off the coast between Palm Beach and Jupiter, Florida. Sharks were observed and filmed swimming and resting on the bottom in large groups estimated to comprise of 50-100 individuals, which is a rare occurrence for this species. Although juvenile lemon sharks are well studied, our understanding of the adult lifestage has largely been extrapolated from studies of juveniles (Kessel et al. 2014). The aggregation at Jupiter consequently provided scientists a first opportunity to reliably study the adult life-stage of lemon sharks. The initial aims of the biotelemetry study were fundamental and included research questions on the maturity of the aggregating sharks, determining if the migration was driven by breeding behaviour and/or environmental factors, and documenting the seasonal distribution of lemon sharks outside of their winter residence in southeast Florida. Given the inherent difficulties of studying large mobile animals in such a large and dynamic ecosystem, it was necessary to adopt a multidisciplinary approach.

\section{$\underline{\text { Biotelemetry }}$}


Over the course of the study (2005-2011), 140 lemon sharks were caught, tagged with NMFS M-Type dart tags (a unique identification number as part of the NMFS Cooperative Shark Tagging Program) and fin clips taken for genetic sampling. Of these, 83 lemon sharks were surgically implanted with acoustic transmitters (V16, Vemco, Nova Scotia, Canada). Throughout the study, hydrophone-equipped receivers (VR2, Vemco) were strategically placed around artificial and natural reef sites stretching $\sim 7 \mathrm{~km}$ to passively monitor tagged individuals (Kessel at al. 2014). The receivers formed part of a larger collaborative network in Florida called the Florida Atlantic Coast Telemetry (FACT) and were also included within the OTN (Fig 1; Kessel et al. 2014).

Results from the biotelemetry data showed a distinct residency period of lemon sharks in southeast Florida from December to April with few individuals detected in the area throughout other months. In addition, through the increased use of passive acoustic biotelemetry along the USA eastern seaboard and collaborative nature of network groups like FACT, Atlantic Cooperative Telemetry (ACT) and OTN, it was also possible to track the movements of lemon sharks outside of the core study area, from as far south as the Dry Tortugas, Florida (minimum distance $\sim 490 \mathrm{~km}$ ), to Cape Hatteras, North Carolina (minimum distance $\sim 1010 \mathrm{~km}$ ) in the north. These region-wide data showed that adult lemon sharks primarily migrate from the north during the fall months, likely driven by seasonal changes in water temperature, and congregate off the coast of southeast Florida when they first encounter the warm waters of the Gulf Stream (Kessel et al. 2014). Biotelemetry data at the core study site, along with diver reports, demonstrated that lemon sharks aggregated in high densities at known locations and predictable times during the winter months potentially making them vulnerable to over exploitation.

Concurrently, a winter aggregation of juvenile lemon sharks was also discovered in the surf zone off the coast of Cape Canaveral during sampling efforts by researchers at the 
Kennedy Space Center, Florida, $\sim 175$ km north of Jupiter. Passive acoustic biotelemetry determined that the juveniles were using the area as a seasonal nursery during the winter months. The sharks made northward migrations during the spring as far as North Carolina and exhibited seasonal philopatry and seasonal fidelity to Cape Canaveral (Reyier et al. 2014).

Genetic samples obtained from both Jupiter and Cape Canaveral determined that even though lemon sharks have a wide, continuous distribution in the Western Atlantic and are seemingly unimpeded by geophysical barriers, there is evidence of a fine scale population structure across their range (Ashe et al. 2015).

\section{Biotelemetry informing State Management}

Changes made to the USA Federal shark management regulations in 2007 included a prohibition on fishing for sandbar sharks (Carcharhinus plumbeus), a highly sought-after species in the commercial fishery (Grubbs et al. 2007). The ban on sandbar shark fishing led to concerns from researchers and advocates that the commercial fishery would replace lost sandbar shark catches by increasing their targeting of lemon sharks. In 2009, the state agency (FWC) announced a review of their shark management policies. Scientists from the Bimini Biological Field Station and Stony Brook University contacted the FWC directly and submitted a report with preliminary biotelemetry and population genetic data that highlighted the spatiotemporal predictability of large aggregations of sharks along with their fine-scale genetic population structure (potentially increasing their vulnerability to over exploitation). After researchers and FWC staff discussed these results and their implications, a proposal was made by FWC to add lemon sharks to the prohibited species list for Florida State waters. The proposal was then presented at several public meetings organized by FWC and was adopted due to a lack of major resistance and the strength of the scientific data provided (Fig. 2). In recognition of the increased vulnerability of lemon sharks to fisheries, the species was 
listed as a prohibited species in Florida State waters in March 2010 to both recreational and commercial harvesting (Fig. 1\&2).

\section{Biotelemetry informing Federal Habitat Management}

Habitat Areas of Particular Concern (HAPC) are subsets of Essential Fish Habitat (EFH) and are habitat types and/or geographic areas identified by NOAA as priorities for habitat conservation, management and research (NMFS, 2016). In 2015, policy makers at NMFS were proposing to amend the Florida EFH boundaries and implement a HAPC for lemon sharks. They reached out to the BBFS research group and Stony Brook University to request the most recent research-related catch data and biotelemetry findings. To date, results from biotelemetry projects in Jupiter (including that detailed in Kessel et al. 2014) and Cape Canaveral (Reyier et al. 2014), in combination with results from the genetic study (Ashe et al. 2015), have been used to implement a HAPC between Jupiter and Cape Canaveral, and update a subset of the EFH, for the lemon shark (Fig. 1, Regional HAPC Report, Oct 2017). Why successful?

Although the lemon shark aggregation research objectives were originally fundamental, independently planned, and minimally funded, the data were successfully incorporated into management. Research has shown that effective science communication increases the uptake of data by stakeholders (Roux et al. 2006; Eden 2011; Fazey et al. 2012; Nguyen et al. 2016; 2012, Cook et al. 2013; Kirchhoff et al. 2013; Cvitanovic et al. 2015, 2016; Meadow et al. 2015; Clark et al. 2016; Nel et al. 2016). In this case, researchers and collaborators were proactive, understood fisheries management in Florida and kept up to date with amendments and opportunities for public comments. Results were actively and openly shared with various audiences, including the FWC, local conservation advocacy groups (Non-Government Organizations, NGOs), and the public through social media network. Although various 
scientific disciplines were used and considered, biotelemetry data provided a unique, spatial aspect to management discussions. Biotelemetry coupled with the various forms of communication all assisted with highlighting the increased vulnerability of lemon sharks during the aggregating season that may not have been obvious in the traditional NMFS annual shark quota surveys.

\section{Case Study 2: Greenland halibut in Cumberland Sound.}

The Canadian Arctic is a relatively pristine region where fisheries are undeveloped compared to temperate/tropical regions, providing opportunity for a cautious approach to fishery development with sustainability as the primary focus (MacNeil et al. 2010). Greenland halibut (Reinhardtius hippoglossides) is a deep-water, circumpolar species that is harvested commercially throughout the Northern Atlantic Ocean (Bowering \& Nedreaas 2000). Prior to the 1980s, Canadian quotas for Greenland halibut were sold to foreign fishing vessels operating in offshore waters (Areas $0 \mathrm{~A}$ and $0 \mathrm{~B}$; Fig. 3) that sold their harvest to processing facilities located in Greenland. With economic development initiatives in the Canadian North, these foreign quotas were gradually re-allocated, in part towards coastal indigenous communities in the Southern Baffin Island region during the 1980s and 1990s (DFO 2006). This reallocation was intended to facilitate in-shore fisheries that benefit the economies of local communities. The coastal community of Pangnirtung, Nunavut began a fishery for Greenland halibut in 1987 and, after high interest from locals and several years of successful test quotas, a commercial quota of 500 tonnes was allocated in 1994, where it currently remains (Fig. 4; CSAS-SAR 2008/040).

Sustainable management of a species requires knowledge of the spatiotemporal structure of exploited stocks, yet little was known about the stock structure of Greenland halibut in this region; given Greenland halibut's wide distribution and panmictic genetic pattern (Vis et al. 1997; Roy et al. 2014), efforts to determine stock structure and define movement patterns 
have typically been isolated to individual management areas. Mark-recapture work undertaken in the fjords of Western Greenland suggested that fish occurring in deep water coastal fjords were resident, sink populations that did not frequently mix with the adjacent offshore population in Baffin Bay and Davis Strait (Boje 2002; Boje et al. 2014) and are consequently managed as two independent inshore and offshore stocks (Nygard 2015). In Baffin Bay, the presence of similar bathymetric features to the Western Greenland fjords prompted similar mark-recapture work to determine if halibut exploited by the Pangnirtung fishery were also reproductively isolated, or part of a larger offshore stock that is also commercially harvested in this region in NAFO 0B (Fig. 3, Stephenson et al. 1997; Treble 2003). These mark-recapture tagging studies, conducted between 1994-2000, experienced low tag returns due to logistical challenges and low recapture rates, however suggested that fish tagged at the entrance of Cumberland Sound moved offshore as part of the offshore stock, while those tagged within the sound were resident, thus indicating the Pangnirtung fishery targeted a discreet stock of Greenland halibut within Cumberland Sound (Treble 2003). Based on these data, the Cumberland Sound Turbot Management Area (CSTMA) was created under scientific advice from the Northwest Atlantic Fisheries Organization Scientific Council (NAFO) to create a separate quota that was only available to the community-based Greenland halibut fishery in Pangnirtung (NAFO 2004).

Greenland halibut catches in the Cumberland Sound management area declined through the 1990 s and early 2000 s due to increasing unpredictability of sea-ice conditions and the loss of fishery equipment due to large storm in 1996 (Dennard et al. 2010), leading to efforts to expand the fishery. Long-line test fisheries were conducted during the open-water season in 2009-2010, and in 2011, Fisheries and Oceans Canada (DFO) initiated annual stock assessment surveys in Cumberland Sound in both the CSTMA and NAFO 0B. Similar to reports from previous tagging efforts (Stephenson et al. 1997), extremely low catch rates were encountered 
by both commercial and test fisheries within the CSTMA in the open water period, however, catch rates in the region immediately south of the CSTMA, in NAFO 0B, were comparatively high. This discrepancy in seasonal Greenland halibut distribution relative to the CSTMA, in conjunction with Inuit Qaujimajatuqangit (Inuit traditional knowledge) of seasonal animal movements within the sound, led to concerns from fishers and the Pangnirtung Hunters and Trappers Association (HTA) that the Greenland halibut stock exploited by the Pangnirtung fishery were moving outside the boundaries of the CSTMA during the open water season, and thus vulnerable to capture in NAFO 0B offshore fisheries not considered in the CSTMA quota.

\section{Biotelemetry}

Considering the CSTMA was established based on depauperate tag-recapture data and observations of Greenland halibut movement in other regions, fishery-independent data on Greenland halibut movement in Cumberland Sound were required to support evidence-based management. Specifically, managers wanted to know if Greenland halibut undertook a seasonal migration between the CSTMA and NAFO OB sectors of Cumberland Sound. Questions and concerns regarding Greenland halibut movements were communicated by fishers to the Government of Nunavut (GN) and DFO. Based on previous and continuing collaborative efforts among organizations, the University of Windsor and OTN initiated a collaboration to address this issue. Given the remote location of the fishery, restricted access, and poor success of tag-recapture studies, acoustic biotelemetry was identified as the most promising tool to address the proposed research question in a timely manner. Preliminary work began in 2010, with a small array of receivers, limited tagged fish $(n=30)$ and extensive acoustic biotelemetry range testing. After successful preliminary trials, a larger array of acoustic receivers was deployed in July 2011, with moorings strategically placed to monitor fish within and outside the CSTMA. Greenland halibut were tagged in two phases representing their suspected 
migratory pattern: within the NAFO OB during the open water period, and within the CSTMA during the ice-covered period in 2012.

Results indicated that while Greenland halibut exhibit variable behaviours, fish did indeed move in and out of the CSTMA between seasons in conjunction with changes in environmental variables such as sea ice extent and benthic dissolved oxygen concentration (Hussey et al. 2017); detection frequencies of fish were highest in the CSTMA during the icecovered period, while fish moved south to deeper waters in Cumberland Sound, outside the CSTMA, during the open water season. Consequently, the community's concern that fish move into NAFO $0 \mathrm{~B}$ waters where they are vulnerable to commercial fishing was validated, and the location of the current management boundary did not effectively delineate the stock as was intended.

\section{$\underline{\text { Biotelemetry informing management }}$}

Data obtained from the acoustic biotelemetry network on the seasonal movements of Greenland halibut were first reported to community members, commercial fisheries operators, and government staff at the annual GN Fisheries and Sealing Division meeting in April 2013. Following discussions at that meeting and recognition that the CSTMA may not accurately reflect the stock distribution as intended, study results and Inuit traditional knowledge from Pangnirtung fishers were presented to the Nunavut Wildlife Management Board (NWMB) at their meeting in July 2013. Because Nunavummiut fisheries are co-managed by the NWMB and DFO, the NWMB recommended to the Minister of DFO that the CSTMA boundary be moved.. As a result, the CSTMA was moved to the 12 nautical-mile boundary of the Nunavut Settlement Area outside of Cumberland Sound to prevent exploitation from the NAFO 0B fisheries and allow the CSTMA quota to cover areas suitable for fishing during open-water. (Fig. 3). However, this boundary movement was conditional on a multi-year study of Greenland halibut movement patterns in Cumberland Sound to determine if the pattern 
observed in the preliminary analysis was consistent across years. The acoustic biotelemetry and mark-recapture programs were extended from 2014-2016 to obtain additional data, and analyses are currently underway. Following presentation of the final peer-reviewed biotelemetry results, the boundary of the CSTMA will either be formalized at its current location or return to its original scope.

Why successful

Through designing a study specifically to address an applied spatial question, biotelemetry data were successfully integrated into the management of the Cumberland Sound Greenland halibut fishery. The path to data integration, however, encountered setbacks that are important to highlight. The project benefited greatly from its collaborative nature, with investigators having varying degrees of history and ongoing interactions with the fishery and fishers. This diversity brought in various perspectives and a broad understanding of the history of the fishery and interpersonal dynamics among the various stakeholders and user groups. Inuit traditional knowledge was integrated in the research planning from the outset; initial research plans were drafted by University of Windsor and DFO researchers and presented to the Pangnirtung HTA for guidance, discussion, and refinement. However, during the first full year of the biotelemetry study (August 2011-August 2012) community members in Pangnirtung became concerned that the biotelemetry moorings were scaring ringed seals (Pusa hispida), which are a cultural and nutritional staple. During a community meeting in June 2012 (prior to the 2012 field season) community elders spoke of their concerns over seeing fewer seals caught and asked about the nature of the biotelemetry equipment. Despite efforts by the research team to demonstrate that the equipment should have minimal impact on marine mammal populations, the concerns of the community members were not allayed. Consequently, the biotelemetry program was cancelled after completing a pilot year in 2010 and one year of full data collection in 2011. All biotelemetry receivers were removed from 
Cumberland Sound in August and September 2012, the data were analysed and a report detailing the observed movements of Greenland halibut between seasons was provided to the Pangnirtung HTA. Subsequently, in the interest of developing a vessel-based open water fishery, the Pangnirtung HTA sent a request to the NWMB for the boundary of the CSTMA be extended to include all of Cumberland Sound, as described above. Given the conditional move of the CSTMA boundary, the Pangnirtung HTA reached out to the biotelemetry research team and after discussing various methods for collecting the required data and presenting those options to the community during an open meeting in February 2014, the biotelemetry study resumed for three additional years (2014-2016) despite previous concerns about the impact on the ringed seals.

The relative fast pace in which biotelemetry data were used to influence management in Cumberland Sound reflects the fishery and the attitudes of its participants and broader stakeholders (GN and DFO) towards fisheries sustainability. It also relates to the clear movement patterns observed in these data, which were visually easy to present and interpret. Biotelemetry provided a powerful visual tool to engage and influence non-academic stakeholders. It is important to note, however, that Inuit traditional knowledge suggested Greenland halibut moved within the Sound prior to the biotelemetry work. Inuit traditional knowledge is a central component in the co-management process and conservation of Arctic species under the Nunavut Land Claims Agreement (NLCA), and the concerns expressed by residents of Pangnirtung over the potential movements of fish were a major factor leading to the investment in research to examine Greenland halibut movements (NWMB-NCRI 2013). At the outset of the biotelemetry study, Inuit traditional knowledge along with DFO fishery data (locations of fishers and catch per unit effort (CPUE)) were used to design the array of receivers. The scale of the open water test fishery was also of benefit as there was only one vessel actively fishing in the NAFO $0 \mathrm{~B}$ portion of the Sound that lost access when the boundary 
was conditionally moved. The overall effect of expanding the CSTMA therefore resulted in few negative impacts to the overall Greenland halibut fishing industry, while simultaneously providing a positive outcome for the community of Pangnirtung.

Many of the coastal Arctic fisheries are still in the exploratory phase, providing the opportunity to develop inshore allocations in a precautionary and sustainable way. As access and interest increase for the resources available in the Northern oceans, we are in a unique position to match development with scientific evidence to describe meaningful stock units and management boundaries. Part of the success in Cumberland Sound was a result of determining the movements of fish early on, before the movement of the management boundary affected many stake-holders, thus reducing conflict. As this is typically not the case in established fisheries, it is likely that change will typically take longer than was observed for the CSTMA, yet this case study provides an optimistic outlook for the development and management of community fisheries throughout the Arctic.

\section{Case Study 3: Biotelemetry in Fraser River Salmon Management}

Pacific salmon Oncorhynchus spp. of the Fraser River in British Columbia, Canada are culturally, economically, and politically important. The watershed drains nearly a quarter of the province and its one of Canada's largest rivers. Hundreds of discreet salmon populations exist throughout. Salmon are an iconic species, symbolic of a healthy environment and thriving economy. Its management leads to regional conflicts among countries (salmon migrate through U.S. waters), regulatory bodies, industry stakeholders, indigenous communities, and environmental groups. Sockeye salmon $O$. nerka are the most commercially valuable species though a major recreational fishery was recently established, and they are critical for First Nations food and ceremonial purposes. Considering the rapidly changing environmental conditions and fluctuating population levels management of the 
Fraser River sockeye is arguably the most complex in Canada (Cohen 2012; Hinch et al. 2012).

Tagging has been used in sockeye research in the Fraser River since transplantation experiments based on visual tag-recapture approaches during the 1920s and 30s (Forester, 1937; Ricker, 1964). Electronic biotelemetry tagging of Fraser sockeye has been occurring since the 1970s (Fretwell 1989). The first large spatial scale biotelemetry projects began in the 1990's through the lab of S. Hinch (University of British Columbia) with the first utilization of electromyogram biotelemetry in salmon (e.g. Hinch et al. 1996; Hinch and Bratty 2000) setting the stage for the physiologic approaches extensively used by OTN investigators (Figure 6). In the early 2000s, the Pacific Ocean Shelf Tracking (POST) project installed acoustic receiver arrays along the west coast of North America while at the same time radio biotelemetry receivers were installed throughout the Fraser River watershed by the environmental consultant company LGL (Hinch et al. 2012). These receiver networks provided the first broad scale network for tracking salmon in both marine and freshwater environments and were instrumental in setting the groundwork and locations for the OTN Pacific telemetric arrays [OTN took ownership in 2012 of some of the POST arrays after that project ended]. Tracking information from this large network was used to estimate stockspecific run timing (English et al. 2005; Hinch et al. 2012) and migration survival rates (Cooke et al. 2004). Hinch and Cooke and their labs developed approaches for non-invasively assessing physiological measures (plasma, tissue, cellular, genomic) of tracked sockeye, which revolutionized understanding of mortality and behavioural mechanisms (reviewed in Cooke et al. 2012) - approaches which were core to OTN research (see Figure 6 for timeline of case study).

\section{Biotelemetry}


In the mid-1990s, a dramatic change in the migratory behaviour of late-run Fraser River sockeye salmon occurred - and this phenomenon has persisted to the present. For reasons unknown, large segments of all late-run populations began entering the river three to six weeks earlier than historical norms (Hinch et al. 2012). Alarmingly, early migrants experienced extremely high in-river and pre-spawn mortality, exceeding $90 \%$ in some years (Cooke et al. 2004). As a conservation measure, managers responded by reducing harvest on late-runs despite their large ocean abundances and on some summer runs because of their now overlapping run timing. These lost fishing opportunities and lost future salmon production cost the fishing industry millions of dollars. Further, a small late-run population, Cultus Lake, was threatened with extinction (Hinch et al. 2012). Scientists and managers from academia, government, and non-government organizations across disciplines (e.g. fisheries biology, oceanography, physiology) met several times in the early 2000's to identify potential causal factors for the changed behaviour and high mortality of late-run sockeye (summarized in Cooke et al. 2004). Biotelemetry was chosen as a key approach for answering the unique suite of hypotheses (Hinch et al. 2012) and a multi-agency research program was launched to understand the causes of the problem (Cooke et al. 2004).

Starting in 2002 and continuing to the present, numerous radio- and acousticbiotelemetry studies were conducted to assess migration behaviour and in-river survival of sockeye salmon from the Fraser River. Fish were tagged in the coastal waters along their migratory routes to assess timing of river entry, migration rates, and mortality. These studies confirmed extremely low survival rates in late-run sockeye that began the riverine phase of their migration early, while late-run sockeye that maintained historical entry timing were more likely to reach spawning grounds (English et al. 2005; Cooke et al. 2006). Further research combined radio or acoustic biotelemetry with physiological and environmental sampling to address causal factors of the observed en-route mortality. Samples collected at 
tagging locations were used to assess reproductive status, available energy, and osmoregulatory state to investigate the physiological drivers of early entry and mortality (Young et al. 2005; Cooke et al. 2008; Crossin et al. 2007). Early-entry migrants were physiologically unique, more advanced reproductive status, lower available energy, and less osmoregulatory preparedness for freshwater transition (Cooke et al. 2006; Young et al. 2006; Crossin et al. 2009). Further, a unique transcriptional signal thought to be indicative of viral infection was associated with mortality in tagged fish, identified through transcriptional micro-array assays (Miller et al. 2011). Early migrants encountered temperatures that were 5$6 \mathrm{C}$ higher than their historical norms, often exceeding their metabolic scope, which, in combination with the above mentioned physiological challenges led to the high mortality (Hinch et al. 2012). This research program provided some of the first insights into the physiological factors underlying anadromous fish migration timing and survival and revealed the extremely strong role that water temperature played in the mortality of migrating salmon (Hinch et al. 2012).

In recent years, the research focus shifted to the study of how high river temperatures, which were getting more commonly encountered by all Fraser salmon stocks, affected migration survival, particularly when faced with additional stressors such as release or escape from fishing gear. Laboratory experiments found that critical temperatures were stockspecific (e.g. Eliason et al. 2011) and tagging studies revealed that handling fish at these temperatures could be catastrophic with delayed mortality rates exceeding $90 \%$ in some situations (Martins et al. 2011). Donaldson et al. (2011) tagged and released sockeye captured in the growing Fraser River summer recreational fishery and found that delayed mortality could be as high as 50\%. Raby et al (2014) tagged and released coho salmon by-catch from in-river beach seine fisheries targeting pink or sockeye salmon and found delayed mortality 
was $39 \%$ - a lower level than with other species or in-river fisheries, possibly owing to cooler fall temperatures.

\section{Biotelemetry Informing Management}

In the case of late-run sockeye, biotelemetry confirmed the early entry behaviour, better quantified mortality rates, and enabled researchers to generate associations between a suite of physiological and environmental factors and mortality (Hinch et al. 2012). The sheer number of highly invested groups in the sockeye salmon fishery creates an incredibly complex and bureaucratic environment where any regulatory changes are heavily scrutinized and slow to progress (Young et al. 2013), however, the physiological biotelemetry information enabled managers to better communicate to the different groups why curtailing the fishery was the appropriate conservation action. The growing understanding of links between stock-specific mortality and critical temperature thresholds derived from biotelemetry (and some laboratory studies) were used to improve quantitative models that predict in-river losses (Macdonald et al. 2010); supporting decisions to reduce fisheries (in all sockeye stocks, not just late-runs) when river temperatures were high and to expand harvest during cooler periods (reviewed in Patterson et al. 2016).

Numerous studies generated delayed mortality estimates for specific species (or stocks) associated with several oceans or in river fisheries (reviewed in Raby et al. 2015b). These estimates are important to fisheries managers as they use them to adjust harvest rates/intensity with the understanding that some amount of bycatch will perish after mandatory release. For example, Raby et al. (2015c) conducted an experimental purse seine fishery for Pacific salmon in the Juan de Fuca Strait, examining whether mortality could be predicted in coho salmon (O. kisutch) bycatch. Short-term mortality was $20 \%$ for biotelemetry-tagged released coho ( 48-96 h) which was lower than the $70 \%$ value that DFO managers were using based on holding studies. From these results, managers adjusted their 
presumed bycatch delayed mortality rate to $50 \%$ thereby enabling enhanced fishing opportunities for other more abundant co-migrating salmon species (Cook et al. 2017). Biotelemetry is an ideal tool to examine delayed mortality for non-retained fish as it can track fish for longer periods than holding studies (e.g., net pens) which is the typical means for getting this data, but some managers and many stakeholders were skeptical of issues with tag burden, small sample sizes, handling effects and distinguishing fisheries-related incidental mortality from natural mortality (Nguyen et al. 2011). In fact, Raby et al (2014) found that most fishers they surveyed believed there was no effect on survival of capture/released coho salmon in their fisheries. This issue culminated in a year-long CSAS (Canadian Science Advisory Secretariat) process wherein all the delayed mortality estimates derived from all the Pacific salmon biotelemetry and related research were reviewed and a framework proposed for how managers are to use this type of science in their decision making (Nguyen et al. In Review CJFAS; Patterson et al. 2017 a, b).

\section{Why successful?}

To address the barriers preventing knowledge uptake in the Pacific fisheries, annually since 2005, the team of primarily academic researchers involved in these studies began holding annual "Research Update and Workshop" symposia with stakeholders (eg. Hinch and Gardner 2009) including First Nations, NGOs, recreational and commercial fishers, academics, and fisheries managers. The objectives were to present research results and receive feedback; encouraging recommendations for future research projects. This proactive framework facilitated the creation of a more positive relationship amongst researchers, First Nations groups and stakeholders while simultaneously exposing stakeholders to the scientific process and barriers to data generation and interpretation. These interactions have created a norm and culture of knowledge exchange in the region and have led to more targeted meetings with fisheries managers and stakeholders to identify relevant research questions. 
Researchers credit this consistent exposure to data from biotelemetry studies during these update meetings as the most important factor in gaining the trust and knowledge uptake of stakeholders in the region. Another factor that contributed to success was that biotelemetry was coupled with other research tools and methods. For example, biotelemetry identified patterns (e.g., of timing or fate) while physiological biopsies and parallel lab experiments identified the mechanisms underlying those patterns (reviewed in Cooke et al. 2012). In that context, the findings from the biotelemetry research contributed to an overall burden of evidence. This is perhaps best exemplified in a paper by Farrell et al. (2008) where the researchers combined field biotelemetry data on survival across different thermal conditions with lab experimental data on how temperature affected organismal performance and survival and found strong concordance between the two datasets.

\section{Synthesis}

Fisheries management is complex, and approaches vary widely across different jurisdictions (e.g. state/province/territory vs federal) and based on numerous factors, including institutional norms, political climate, targeted species, number of fishing sectors involved, the size of fishery, and the number and engagement of user groups. Management organizations often strive for science-based policies, but barriers to incorporating new evidence, or evidence obtained from 'new' technologies' exist (Young et al. 2016). Using the OTN's network of researchers and their experiences, we have explored some rarely-published 'behind the scenes' processes from cases where biotelemetry information has been successfully incorporated into fisheries management. Among our case studies, biotelemetry data have been used to prohibit the harvest of a species within a management zone, determine adaptive harvest rates, define Essential Fish Habitat boundaries, re-define management zones, and reduce uncertainty in complex fisheries models to improve management of fish populations. 
Though each research project is innately unique, certain characteristics shared among the case studies may contribute to the successful use of biotelemetry data in fisheries management decisions. We attempted to select parameters that we felt either hindered or contributed to the integration of biotelemetry knowledge. These parameters include the economic value of the fishery, the original research objectives, the type of biotelemetry data produced, the level and complexity of management involvement, and various forms of communication (Table 1).

Interestingly, there were few similarities (of parameters) among the three case studies (Table 1). Each case spanned a magnitude of economic value (from less than one million USD (Florida) to hundreds of millions CAD (BC)), varied in duration from several years to multiple decades, and demonstrated different amounts of collaboration and engagement with managers. Even the original objectives of the studies differed in where they were positioned along the fundamental-applied continuum, with Florida research initially being completely fundamental, while Cumberland Sound and BC cases could be considered more applied. Finally, the numbers of publications and technical reports varied considerably, with only three documents produced related to the Florida project, to several hundred for the BC case. These vast differences in project structure, value and longevity and published output highlight the importance of case-by-case science communication initiatives.

In each case, it was active and ongoing communication outside of peer-reviewed and traditional science communication and the visual evidence of fish movements, presence or absence that were critical in engaging all parties with a vested interest. In Florida, direct and two-way communication with the managers enabled preliminary and peer-reviewed results to be considered in policy changes. In Cumberland Sound, because the initial concern that led to the biotelemetry project was brought forth by the community, it was critical to ensure local stakeholders and indigenous groups maintained their voice and that they were empowered 
throughout the research process. Co-production of the research agenda through meetings with stakeholders, managers, and the research team, along with a pilot tagging study, created a strong foundation for buy-in that biotelemetry was the appropriate tool to answer the research question despite challenges that occurred along the way. Over the time frame of the project, continued communication and presentations of updated results with the HTA, the broader community, fishermen and relevant territorial organizations (NWMB, GN Fisheries and Sealing) were essential to overcome cultural questions over the impact of the technology used and to derive the final data needed to directly address management. Finally, in BC, the long and well-established history of communication among stakeholders - though often driven by conflict - was a platform that researchers could leverage to increase exposure to fisheries research in the region. Early, consistent, and repetitive exposure to findings from multiple projects indicating certain factors predictably influence mortality was integral to the integration of biotelemetry data into management. Fisheries managers were presented strong and repeatable estimates for en-route mortality of salmon as well as the physiological mechanisms associated with the phenomena leading not only to a more robust management approach based on scientifically informed environmental thresholds, but also a more collaborative and communicative research environment in the region.

Another commonality was the interdisciplinary nature of the research agendas and the research teams. For most of our examples, biotelemetry methods were not the single factor influencing management change, but rather paired with other biological sampling methods such as genomics, physiology and oceanography. For example, in Florida, population genetic analysis complemented the migration data by determining the local population was discrete and isolated, and therefore more vulnerable to overexploitation. In Cumberland Sound, biotelemetry was introduced after several years of fisheries monitoring (locations of fishing effort and quantified catch per unit effort data), mark-recapture research, Inuit traditional 
knowledge that identified issues of priority, and oceanographic data was key to explaining the potential drivers of seasonal movements of fish and factors impacting fishing (i.e. sea ice reduction). In BC, biotelemetry was used to field-validate previous laboratory work with regards to temperature tolerance levels and mortality rates. Furthermore, biotelemetry was coupled with physiological measurements, genomic information, and environmental data to offer a more holistic understanding of the observed behaviours and mortalities recorded using biotelemetry technology. The coupling of various techniques and the contribution of different disciplinary perspectives offered a more robust scientific knowledge to the various issues. Many fisheries management problems are inherently complex, so multiple disciplinary perspectives are essential for generating the synthetic understanding needed to inform management (Dick et al. 2016).

It also appeared that the type of information generated from biotelemetry played a role in its integration. In cases (Florida and Cumberland Sound) where biotelemetry informed the spatial distribution or delineation of areas in which species are present/absent, integration of such information was much more readily accepted. Similarly, the information about spatial distribution in the $\mathrm{BC}$ case study were those that were more readily incorporated (e.g. migratory timing) compared to mortality estimates incorporating multiple factors. With a well-designed study, the data are not easily refutable as it offers visual evidence of presence/absence and movement of fish and increased the stakeholder buy-in. For example, visual fish tracks are extremely useful for conveying fish movement to stakeholders and various user groups, and there is generally no contesting the movement patterns/behavior observed.

\section{Lessons learned}

It has been touted that the co-production of the research agenda by user groups is critical to successful uptake of knowledge (Young et al. 2013; Meadow et al. 2015; Fazey et 
al. 2012; Clark et al. 2016), and we have demonstrated that this is true in certain cases, but not necessarily all. That is, co-production is useful but not an inherent requirement of mission-oriented research. In general, the complexity, sociopolitical, and economic impact of the management change associated with the research will likely dictate the management buyin and strength of evidence that is required (Nguyen et al. accepted in CJFAS). Here, these sociopolitical challenges are demonstrated succinctly by comparing the amount of engagement effort on part of the researchers with the size and complexity of the fishery surrounding the studied species. While advanced and scientifically informed management change was initiated by the biotelemetry research findings in Florida, less than $4 \%$ of the state fishery was even marginally affected, and public opinion likely played an appreciable role in the ease that management change was adopted. In Cumberland Sound, indigenous stewardship paired with the desire for increased economic opportunity resulted in a relatively speaking - straightforward research question based around current management practices. However, even though the fishery in question is small and relatively new, and the management change straightforward, co-production of the research agenda with Inuit residents was a necessity not only for stakeholder and indigenous group buy-in, but because community support for research is dictated by Nunavut legislation. Here, ongoing indigenous group engagement was necessary, and additional demand for follow-up research through continued monitoring was a condition of the management change. Finally, Pacific salmon is one of the most researched fish assemblages in the world with an incredibly complex management system to match. Unsurprisingly, management has benefitted from the prodigious research, especially the integration of biotelemetry science with management objectives, but this integration is highly nuanced and the direct translation of science information to management decisions is often cryptic to outside observers (Patterson et al. 2016). Institutional resistance in the management system, driven in part by high monetary 
value of the fishery and complex relationships among vested interest groups, have limited the amount of and speed at which new information can change management practices (Young et al. 2014). Indeed, it has taken major shifts in salmon survival to a point where the future of the fishery was in jeopardy for a push for more science on salmon migration biology; each successive political-based review spawned new biotelemetry research (eg. Fraser 1994; Williams 2005; Cohen 2012). Unlike what has been observed in smaller and less complex fisheries, and despite efforts of many in science, management and user groups, there remains a persistent criticism that scientific advice has been too slowly integrated into the management of Fraser River Salmon fisheries (Cohen, 2012).

Whether findings revealed during targeted applied research or stumbled across during theoretical studies, there is opportunity to engage with managers and other user groups to improve the science behind management practices. Thus, we believe maintaining positive and active relationships with relevant stakeholder groups, regardless of the direct applicability of the research, is the most important action research teams can take to ensure their data may be used to impart real change in management and conservation. This is a common theme running through each case study and has recently been isolated as an important factor in research on trust and knowledge mobilization in fisheries management (reviewed in Nguyen et al. 2017; Alexopoules and Buckley 2013; Young et al. 2016a). Most importantly, willingness and motivation to embark on a path of continuous, honest and transparent engagement among researchers and managers/stakeholders are a key ingredient. Often, these engagements and collaborations take time and patience, which take away from other roles, responsibilities, and potential career advancements, however, building trust of not only the scientific techniques and equipment, but of the researchers is important. Strategic networking to establish open communication and trust among relevant user groups can remove political 
and/or bureaucratic barriers that would otherwise prevent user groups from engaging with biotelemetry research.

Information regarding the processes involved with successful knowledge mobilization are rarely documented in peer-reviewed literature, however this information is incredibly valuable and of interest to many conservation scientists. As we have experienced while writing this piece, it is challenging to trace scientific evidence that contributed to management changes for complex management systems. Networks, such as OTN, provide forums for knowledge sharing on lessons learned and development of skills to engage in iterative and active communication. Greater investments and attention by networks, funding agencies, and other institutions, to develop these skills are sorely needed to foster positive and active relationships that can impart real change in management and conservation.

\section{Acknowledgements}

The authors wish to acknowledge the support and funding provided by the Ocean Tracking Network. For the Florida case study, funding was primarily provided by the Swiss Shark Foundation - Hai Stiftung, and additionally by the National Geographic Society, Bimini Biological Field Station Foundation and Guy Harvey Ocean Foundation. We acknowledge all FACT and ACT members, particularly Joy Young with the FWC Tequesta Lab and Eric Reyier at Kennedy Space Centre, who provided lemon shark detections outside of the personal acoustic coverage. For the Cumberland Sound case study, funding was provided by the Government of Nunavut. We would like to thank the Hunters and Trappers Association in Pangnirtung, Peter and Robbie Kilabuk, The Nunavut Wildlife Management Board, and the crew of the Nuliajuk. For the BC case study, we thank the Southern Endowment Fund of the Pacific Salmon Commission, the Fraser River Environmental Watch Program of DFO, 
Genome BC, and the Natural Sciences and Engineering Research Council of Canada for funding the work on the early-migration phenomenon in late-run $O$. nerka salmon. 
Table 1. Parameters (with approximated responses) used to discuss and compare the scale and complexities of the fisheries and that facilitated of inhibited successful incorporation of biotelemetry data into management.

\begin{tabular}{|c|c|c|c|c|}
\hline Parameter & Description & Florida & Cumberland Sound & BC \\
\hline $\begin{array}{l}\text { Economic value of } \\
\text { fishery }\end{array}$ & & 〜CAN\$1million & $\sim$ CAN\$2 million & $\sim$ CAN\$100s millions \\
\hline Lead organization & $\begin{array}{l}\text { Who conducted the } \\
\text { biotelemetry project(s) }\end{array}$ & NGO & $\begin{array}{l}\text { Academic and } \\
\text { Government Scientists }\end{array}$ & $\begin{array}{l}\text { Academic and } \\
\text { Government } \\
\text { Scientists }\end{array}$ \\
\hline $\begin{array}{l}\text { Original research } \\
\text { objective }\end{array}$ & Applied or Fundamental & Fundamental & Applied & Applied \\
\hline $\begin{array}{l}\text { Fisheries and } \\
\text { habitat } \\
\text { management } \\
\text { involved? }\end{array}$ & $\begin{array}{l}\text { Were government } \\
\text { scientists or managers } \\
\text { involved at any stage of } \\
\text { the biotelemetry } \\
\text { research? }\end{array}$ & No & Yes & Occasionally \\
\hline If so, what stage(s)? & $\begin{array}{l}\text { Planning, Fieldwork, } \\
\text { Analysis, Write up. }\end{array}$ & N/A & All stages. & Planning. \\
\hline Time span & $\begin{array}{l}\text { Number of years since } \\
\text { first tag deployed }\end{array}$ & $<10$ years & $\begin{array}{l}3 \text { years }+3 \text { following } \\
\text { conditional } \\
\text { movement. }\end{array}$ & $>40+$ years \\
\hline $\begin{array}{l}\text { Approximate } \\
\text { number of peer- } \\
\text { reviewed } \\
\text { publications }\end{array}$ & $\begin{array}{l}\text { Number of peer- } \\
\text { reviewed publications }\end{array}$ & 1 & 2 & $\sim 100$ \\
\hline
\end{tabular}




\begin{tabular}{|c|c|c|c|c|}
\hline $\begin{array}{l}\text { Approximate } \\
\text { Number of technical } \\
\text { reports }\end{array}$ & $\begin{array}{l}\text { Number of technical } \\
\text { reports }\end{array}$ & 1 & $\begin{array}{l}6 \text { (annual reports to } \\
\text { Hunters and Trappers } \\
\text { Organization) }\end{array}$ & $>50$ \\
\hline $\begin{array}{l}\text { Approximate } \\
\text { number of } \\
\text { presentations }\end{array}$ & $\begin{array}{l}\text { Number of presentations } \\
\text { to managers or } \\
\text { stakeholders (not } \\
\text { general conference } \\
\text { presentations) }\end{array}$ & 3 & 14 & $>500$ \\
\hline $\begin{array}{l}\text { Number of meetings } \\
\text { with managers }\end{array}$ & $\begin{array}{l}\text { Number of meetings } \\
\text { with management }\end{array}$ & 3 & 20 & $>200$ \\
\hline
\end{tabular}
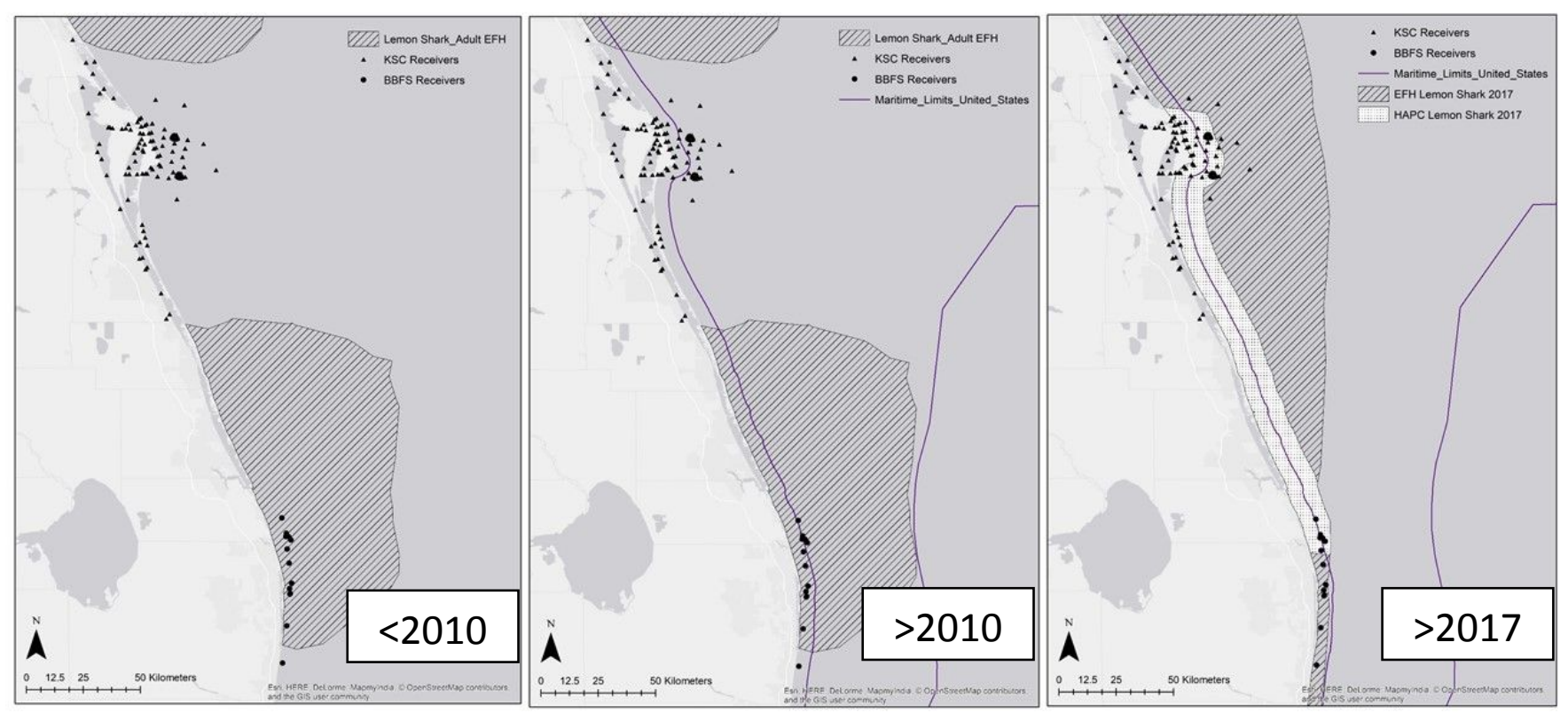

Figure 1: Various stages of management of lemon shark fisheries and habitat in southeast

Florida, USA. Pre- 2010 map shows Bimini Biological Field Station acoustic biotelemetry 
array $(\bullet)$ and Kennedy Space Center array $(\boldsymbol{\Delta})$ and lemon shark Essential Fish Habitat (EFH) boundary. Lemon sharks were subject to capture and harvest in all areas. Post-2010, harvest of lemon sharks is prohibited up to State line $(<3$ nautical miles from shoreline, i.e. the line closest to shore). Post-2017 includes prohibition of harvest in State waters, an updated EFH boundary and a new Habitat Area of Particular Concern (HAPC) connecting both aggregating sites (Jupiter and Cape Canaveral). HAPC and EFH shapefiles obtained from NMFS (NMFS, 2017) and plotted in ArcMap 10.5.1 (ESRI, 2017). Base map obtained from ESRI, HERE, DeLorme, MapmyIndia COpenStreetMap contributors and the GIS user community. 


\section{Management}

NMFS prohibits sandbar harvestpotential shift to target lemon sharks.

FWC announces it is reviewer its shark management policies

Technical report submitted to FWC Presented at FWC

Lemon sharks receive State protection

\section{Telemetry}

Divers notify BBFS aggregation of lemon sharks

Dives made on the aggregation by shark lab staff to assess and confirm presence/reliability

2006 Tagging pilot study

2007

Tagging study fully initiated

2014 Kessel et al., 2014

Predictable temperature-regulated residency, movement and migration in a large, highly mobile marine predator.

Reyier et al., 2014

Regional-Scale Migrations and Habitat Use of Juvenile Lemon Sharks (Negaprion brevirostris) in the US South Atlantic

NMFS Harvest rate controlledIf $20 \%$ reached, fishery closed until July

2015 Ashe et al., 2015 Local population structure and contextdependent isolation by distance in a large coastal shark.

BBFS presents to HMS meeting, Bethesda, MD

Updated EFH and HAPC boundaries open for public comment

EFH and HAPC boundaries finalized- 2017 expanded using telemetry data 
Figure 2. Timeline of lemon shark biotelemetry research in Florida, USA, illustrating the management and research processes. Management changes are bolded. (National Marine Fisheries Service (NMFS), Florida Fish and Wildlife Commission (FWC), Essential Fish Habitat (EFH), Habitat Area of Particular Concern (HAPC), and Bimini Biological Field Station (BBFS)). 


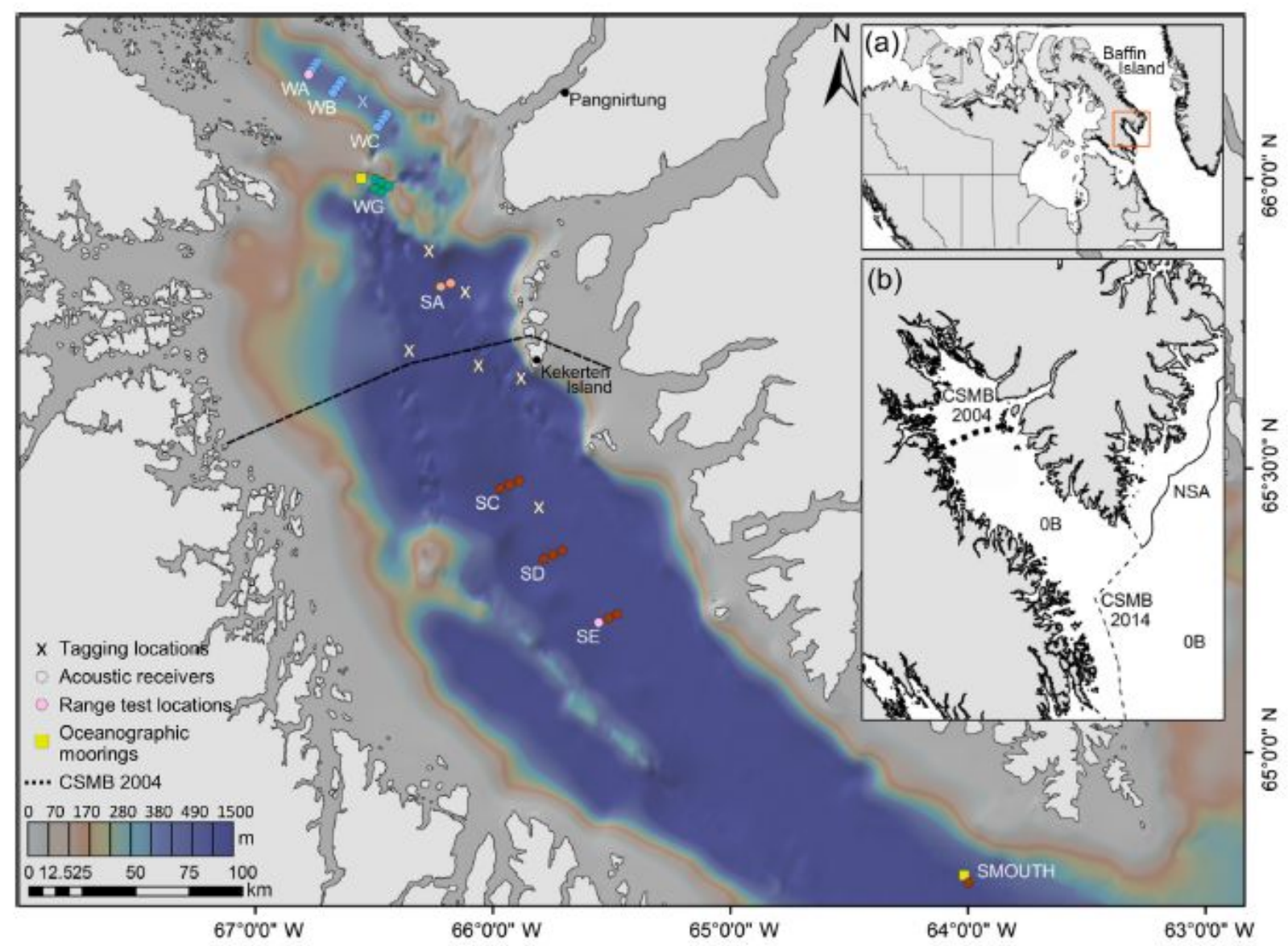

Figure 3. Map of the study site within Cumberland Sound. Circles indicate the locations of individual acoustic receivers, where red identifies receivers located in the southern, deepwater environment; light red are receivers located in the deep-water area north of the Cumberland Sound Management Boundary (CSMB); blue are receivers located in the northern, shallow-water environment; and green are receivers forming a gate across a deepwater channel dividing the shallow and deep-water regions. The label next to each row of receivers indicates the name of those stations. The locations of fixed oceanographic moorings, range tests and the CSMB established in 2004 are shown. Fish tagging locations are marked with X; yellow X are Greenland halibut tagged in August 2010 and 2011, and blue $\mathrm{X}$ is Greenland halibut tagged in April 2012. Inset (a) indicates the location of Cumberland Sound on the southeast side of Baffin Island, Nunavut, Canada. Inset (b) indicates fisheries and resource management boundaries in the region. The location of the 
CSMB in 2004 is designated with a thick dashed line within Cumberland Sound, and the relocated boundary (CSMB 2014) is shown by a thin dashed line connected to the Nunavut Settlement Area (NSA), a 12-nautical-mile $(22.2 \mathrm{~km})$ offshore boundary reserved exclusively for indigenous fishing rights. Northwest Atlantic Fisheries Organization (NAFO) management Division 0B (Southern Cumberland Sound prior to 2014 and Davis Straight) are also indicated (Obtained from Hussey et al. 2017). 


\begin{tabular}{|c|c|c|}
\hline Management & & Telemetry \\
\hline $\begin{array}{l}\text { Government of the Northwest Territories } \\
\text { sponsored visit by Greenlandic fishers to } \\
\text { demonstrate ice fishing method. }\end{array}$ & 1986 & \\
\hline $\begin{array}{l}\text { Inuit fishery first established-First year of } \\
\text { exploratory fishing. }\end{array}$ & 1987 & \\
\hline TAC set at $500 \mathrm{t}$. & 1990 & \\
\hline $\begin{array}{l}\text { Mark-recapture study began - floy tags applied } \\
\text { in summer. 1994-2004 study) }\end{array}$ & 1994 & \\
\hline $\begin{array}{l}\text { Resident inshore fish population determined } \\
\text { from mark-recapture work/ designation of } \\
\text { Cumberland Sound Turbot Management Area } \\
\text { (CSTMA). } \\
\text { NAFO SC } 04 / 20 \text { and NAFO SC resolution. }\end{array}$ & 2004 & \\
\hline $\begin{array}{l}\text { GN sponsored exploratory fishing by } 82^{\prime} \text { longline } \\
\text { vessel (Stelie II) in CSTMA. }\end{array}$ & 2009 & \\
\hline $\begin{array}{l}\text { GN sponsored exploratory fishing by } 49^{\prime} \text { longline } \\
\text { vessel (L'Anse Amour Venture) in CSTMA. } \\
\text { Commercial fishing by } 82^{\prime} \text { longline vessel in } \\
\text { NAFO OB portion of Cumberland Sound (i.e. } \\
\text { south of the CSTMA). }\end{array}$ & 2010 & $\begin{array}{l}\text { Preliminary telemetry work begins (tagging/few } \\
\text { monitors) }\end{array}$ \\
\hline $\begin{array}{l}\text { GN holds annual fishery science planning } \\
\text { meetings. Biotelemetry results presented in } \\
\text { 2011-2017. } \\
\text { First year of vessel-based depth stratified fishery } \\
\text { independent survey. } \\
\text { DFO holds annual planning meetings with } \\
\text { Pangnirtung HTA. Presentation of results and } \\
\text { submission of technical reports from 2011-2016. }\end{array}$ & 2011 & More intensive tagging/acoustic array deployed \\
\hline $\begin{array}{l}\text { Open community meeting with Pangnirtung HTA } \\
\text { to discuss concerns about seals. }\end{array}$ & 2012 & $\begin{array}{l}\text { Fish tagged in the winter fishery (april)-results } \\
\text { come back in September that fish are crossing } \\
\text { management boundary }\end{array}$ \\
\hline $\begin{array}{l}\text { Presentation of data at Nunavut Wildlife } \\
\text { Meeting (Rankin Inlet - July 2013) }\end{array}$ & 2013 & \\
\hline $\begin{array}{l}\text { Meeting in February } 2014 \text { in Pangnirtung with } \\
\text { community - seek whether community was } \\
\text { committed to supporting continuation of } \\
\text { monitoring - this was requisite if conditional } \\
\text { move of boundary was to take place. } \\
\text { Open community meeting with Pangnirtung HTA } \\
\text { to discuss and refine the reboot of biotelemetry } \\
\text { study. }\end{array}$ & 2014 & $\begin{array}{l}\text { Monitoring resumes - modified acoustic array } \\
\text { deployed in consultation with Pang } \\
\text { community/fishermen - reduced array. Fish } \\
\text { tagged summer } 2014 \text {. } \\
\text { Telemetry work continues to determine if } \\
\text { seasonal patterns are repeated over multiple } \\
\text { years. }\end{array}$ \\
\hline $\begin{array}{l}\text { Official decision to temporarily move the } \\
\text { boundary line to the mouth of Cumberland } \\
\text { Sound, designating the entire inshore area } \\
\text { solely for Inuit fisheries, with permanency } \\
\text { pending the results of two additional years of } \\
\text { fish tracking }\end{array}$ & $\begin{array}{l}2016 \\
2017\end{array}$ & $\begin{array}{l}\text { Telemetry monitoring continues. All equipment } \\
\text { removed from water in September } 2016 \text {. } \\
\text { Hussey et al. 2017, Movements of a deep- water } \\
\text { fish: establishing marine fisheries management } \\
\text { boundaries in coastal Arctic waters }\end{array}$ \\
\hline
\end{tabular}


Figure 4. Timeline of Greenland halibut biotelemetry research in Nunavut, Canada, illustrating the management and research processes and progression. Management changes are bolded. $(\mathrm{TAC}=\mathrm{Total}$ Allowable Catch; Cumberland Sound Turbot Management Area (CSTMA); Government of Nunavut (GN), North Atlantic Fisheries Organization (NAFO)).

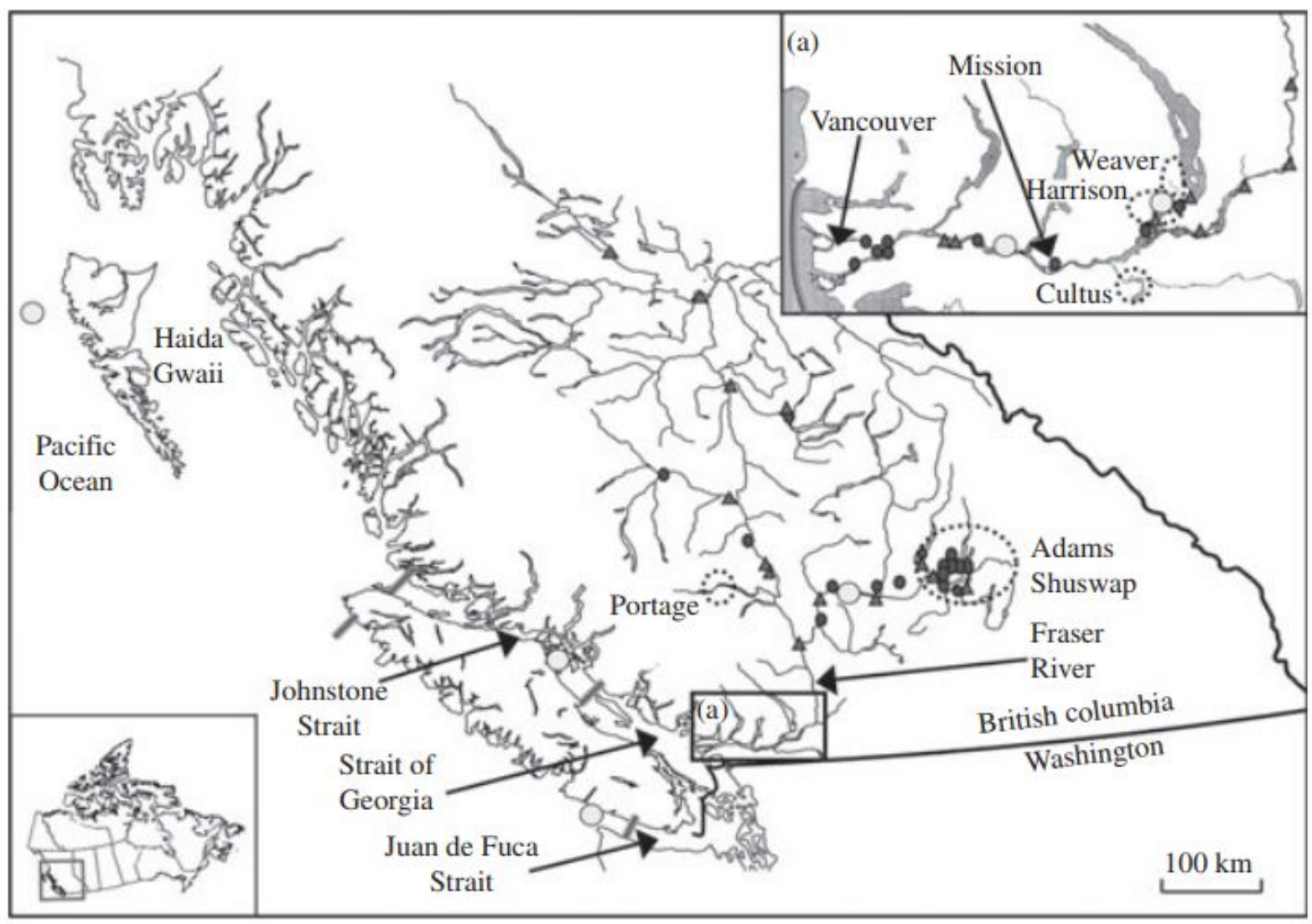

Figure 5. Map of southern half of British Columbia, with an inset of Canada, and an inset (a) showing the lower Fraser River. The Fraser River main stem and its main tributaries and lakes are indicated. Circled and labelled are spawning areas (by name) for late-run Oncorhynchus nerka populations. Shown are $O$. nerka tagging and release locales $(\mathrm{O})$, acoustic receiver curtain lines $\left(\_\right.$, , associated with the Pacific Ocean Shelf Tracking project (P) and other groups, sentinel acoustic receivers ( $\bullet$, maintained by Kintama Ltd and the University of British Columbia), and sentinel radio receivers ( $\boldsymbol{\Lambda}$, maintained by LGL Ltd) that existed with various modifications during most of the studies that are 
reviewed. Acoustic receiver locations are shown in inset map (a) represent pairs of receivers.

(Obtained from Hinch et al. 2012) 


\section{Management}

Larkin Report, first to more research on temperature effects on sockeye.

Fraser Inquiry 1994 sockeye fishery - propose predictive temperature models and more research on temperature effects on salmon migration.

1995 - First use of adjustments of harvest for expected in-river mortality of environmental information to adjust sockeye harvest Results included in the 'Fraser River Sockeye Public Review Board' set up by Canadian Government (Fisheries Minister B. sockeye.

2001 - DFO and Pacific Salmon Commission ask researchers to plan for investigations in causes and consequences of early entry late run behaviour; start of several million dollars worth of telemetry projects in 2000 's

2002 - Consistent use of harvest adjustments to mitigate for environmental conditions and timing for all stock groupings

$2002-2005$ - DFO adopts Wild salmon policy, places conservation of salmon as first priority for salmon resource management

2005 - Judge Williams Inquiry on 2004 missing fish recommends more research on temperature and fishing interaction in relation to en route mortality 2005 - Parliamentary standing committee for DFO recommends more research on fish migration timing, 2012 en route mortality and post-release or escape mortality

Federal inquiry into missing sockeye salmon 'The Cohen Commission' begins and relies on field/lab data and expert knowledge from OTN investigators (Hinch 2010 and Miller) to help in its 2 year investigation.

1990
1999 - Canada-US Pacific salmon treaty-recommends use Tobin) to investigate the disappearance of millions of

\section{Telemetry}

1993 -First large spatial scale application of physiological (EMG radio) telemetry on migrating fish (Funded through Canada's Green Plan).

2001- Studies initiated by Pacific Ocean Salmon Tracking (POST) involving acoustic telemetry (Welch et al., 2003). POST and its arrays were precursors to OTN. 2002 -First major telemetry study (radio) focused on population-scale sockeye mortality (English et al., 2005). 2003-08 -NSERC and Pacific Salmon Commission fund large multi-institutional and

2005 multi-PI research program to understand Fraser sockeye issue.

2006 -Experimentally thermally treated and tracked fish, first direct evidence warm water temps cause high mortality.

2006-08 -Mounting evidence showing strong agreement between lab-generated studies of stock-specific thermal migration performance and field telemetry data.

2008-12 - NSERC and GenomeBC fund large programs to investigate effects of climate change

2008- and fisheries in physiology, genomics, and survival of migrating Fraser River sockeye. First research to understand the physiology of natural senescence and mortality in Pacific salmon and starting to quantify delayed mortality associated with capture/release fisheries.

20102010 -Largest telemetry study to date $(>1200$ fish) showing direct relationship between stock specific mortality and specific river temperatures.

First study to ever show, via telemetry and genomics, the link between migration survival and physiology in fish.

Ocean Tracking Network studies funded to generate science needed to understand issues related to migration failure in juvenile and adult sockeye salmon.

2012 - Judge Cohen's commission on Sockeye Declines identifies high temperatureand in-river mortality as key factors (based primary on telemetry to date) and recommends work on cumulative impacts and fishing interactions

2013 - First use and adoption of timing models based on telemetry results to generate post-season mortality estimates for specific stocks

OTN investigators develop Canadian Science Advisory Secretariat (CSAS) guidelines for DFO fisheries managers.

2014 - DFO fisheries management formally requests Science to review information on post-release mortality of Pacific Salmon 2010-

-New technologies developed including broad-scale acoustic accelerometers for studying swimming speeds and energetics, and large-scale use of highly miniaturized transmitters in the study of out migrating juvenile sockeye salmon.

2013- Lab and field studies examined delayed

2016 mortality in adult salmon released/escaped from fisheries under current climate and climate warning scenarios, quantifying the associated mortality rates.

$>3000$ acoustic tags, $>1000 \mathrm{~km}$, tracked juveniles revealed most fish perish during first few days of out migration due to predation.

2015- First large-scale integration of social science

2017 (Knowledge Mobilization research) into

2017 telemetry and fisheries catch and release science. 
2 Figure 6. Timeline summarizing the Pacific salmon (Oncorhynchus spp) biotelemetry research in British

3 Columbia, Canada, illustrating the management and research processes and progression.

4

$5 \quad$ References

6 Ashe, J. L., Feldheim, K. A., Fields, A. T., Reyier, E. A., Brooks, E. J., O’Connell, M. T., ... \&

7 Chapman, D. D. (2015). Local population structure and context-dependent isolation by distance in a 8 large coastal shark. Marine Ecology Progress Series, 520, 203-216.

9

10 Banneheka, S. G., Routledge, R. D., Guthrie, I. C., \& Woodey, J. C. 1995. Estimation of in-river fish

11 passage using a combination of transect and stationary hydroacoustic sampling. Canadian Journal of

12 Fisheries and Aquatic Sciences, 52(2), 335-343.

13

14 Boje, J. 2002. Intermingling and seasonal migrations of Greenland halibut (Reinhardtius

15 hippoglossoides) populations determined from tagging studies. Fisheries Bulletin, 100, 414-422.

16

17 Boje, J., Neuenfeldt, S., Sparrevohn, C. R., Eigaard, O., \& Behrens, J. W. 2014. Seasonal migration, 18 vertical activity, and winter temperature experience of Greenland halibut Reinhardtius hippoglossoides

19 in West Greenland waters. Marine Ecology Progress Series, 508, 211-222.

21 Bowering, W. R., \& Nedreaas, K. H. 2000. A comparison of Greenland halibut (Reinhardtius

22 hippoglossoides (Walbaum)) fisheries and distribution in the Northwest and Northeast

23 Atlantic. Sarsia, 85(1): 61-76. 
24 Brooks, J. L., Guttridge, T. L., Franks, B. R., Grubbs, R. D., Chapman, D. D., Gruber, S. H., ... \&

25 Feldheim, K. A. (2016). Using genetic inference to re-evaluate the minimum longevity of the lemon 26 shark Negaprion brevirostris. Journal of fish biology, 88(5), 2067-2074.

27

28 Carlson, J. K., Hale, L. F., Morgan, A., \& Burgess, G. 2012. Relative abundance and size of coastal 29 sharks derived from commercial shark longline catch and effort data. Journal of Fish Biology, 80(5),

30

31

32

33 34

8

Clark, W.C., Van Kerkhoff, L., Lebel, L., and Gallopin, G.C. 2016. Crafting usable knowledge for sustainable development. Proc. Natl. Acad. Sci. 113(17): 4570-4578. doi:10.1073/pnas.1601266113.

Cohen, BI (2012) Commission of Inquiry into the Decline of Sockeye Salmon in the Fraser River: The Uncertain Future of Fraser River Sockeye, Volume 1: The Sockeye Fishery. Public Works and Government Services Canada, Ottawa, ON, Canada, pp 1-722.

Compagno, J. V. L. 1984. FAO species catalogue Vol. 4, part 2 sharks of the world: An annotated and illustrated catalogue of shark species known to date. Food and Agriculture Organization of the United Nations.

Cook, C.N., Mascia, M.B., Schwartz, M.W., Possingham, H.P., and Fuller, R.A. 2013. Achieving conservation science that bridges the knowledge-action boundary. Conserv. Biol. 27(4): 669-678. doi:10.1111/cobi.12050. 
47 Cook, K.V., Lennox, R.J., Hinch, S.G., Cooke, S.J. 2015. Fish out of water: How much air is too much 48 for released fish? Fisheries 40(9):452-461.

49

50 Cook, K.V., Hinch, S.G., Drenner, S.M., Halfyard, E.A., Raby, G.D., and Cooke, S.J. 2017. Population51 specific mortality in coho salmon (Oncorhynchus kisutch) released from a purse seine fishery. ICES

52 Journal of Marine Science. 75(1), 309-318

Cooke, S.J., Hinch, S.G., Farrell, A.P., Lapointe, M.F., Jones, S.R.M., Macdonald, J.S., Patterson, D.A., Healey, M.C., and Van Der Kraak, G. 2004. Abnormal migration timing and high en route mortality of sockeye salmon in the Fraser River, British Columbia. Fisheries, 29(2): 22-33.

Cooke, S. J., Hinch, S. G., Crossin, G. T., Patterson, D. A., English, K. K., Healey, M. C., ... \& Farrell, A. P. 2006. Mechanistic basis of individual mortality in Pacific salmon during spawning migrations. Ecology, 87(6), 1575-1586.

Cooke, S. J., Hinch, S. G., Crossin, G. T., Patterson, D. A., English, K. K., Healey, M. C., Macdonald, J. S., Shrimpton, J. M., Young, J. L., Lister, A., Van Der Kraak, G. \& Farrell, A. P. 2008. Physiological correlates of coastal arrival and river entry tim- ing in late summer Fraser River sockeye salmon (Oncorhynchus nerka). Behavioural Ecology 19, 747-758.

Cooke, S.J., Hinch, S.G., Donaldson, M.R., Clark, T.D., Eliason, E.J., Crossin, G.T., Raby, G.D., Jeffries, K.M., Lapointe, M., Miller, K., Patterson, D.A., Farrell, A.P. (2012) Conservation physiology in practice: How physiological knowledge has improved our ability to sustainably manage Pacific salmon during up-river migration. Philosophical Transactions of the Royal Society of London B 367: 1757-1769. 
68 Cooke, S.J., Nguyen, V.M., Murchie, K.J., Thiem, J.D., Donaldson, M.R., Hinch, S.G., Brown R.S., and

69

70

71

72

73

74

75

76

77

78

79

80

81

82

83

84

85

86

87

88

89

90

91

80

Fisk. A. 2013. To tag or not to tag: animal welfare, conservation and stakeholder considerations in fish tracking studies that use electronic tags. Journal of International Wildlife Law \& Policy 16: 352-374.

Cooke, S.J., Martins, E.G., Struthers, D.P., Gutowsky L.F.G., Power M., Doka S.E., Dettmers J.M., Crook D.A., Lucas M.C., Holbrook C.M. and Krueger, C.C. 2016a. A moving target - incorporating knowledge of the spatial ecology of fish into the assessment and management of freshwater fish populations. Environmental Monitoring and Assessment. 188:Article \#239.

Cooke, S.J., Hinch, S. G., Crossin, G. T., Patterson, D. A., English K. K., Shrimpton J.M., Van Der Kraak, G., and Farrell, A. P. 2016b. Physiology of individual late-run Fraser River sockeye salmon (Oncorhynchus nerka) sampled in the ocean correlates with fate during spawning migration. Canadian Journal of Fisheries and Aquatic Sciences 63(7): 1469-1480.

Crossin, G. T., Hinch, S. G., Cooke, S. J., Cooperman, M. S., Patterson, D. A., Welch, D. W., ... \& Farrell, A. P. 2009. Mechanisms influencing the timing and success of reproductive migration in a capital breeding semelparous fish species, the sockeye salmon. Physiological and Biochemical Zoology, 82(6), 635-652.

Crossin, G. T., Heupel, M. R., Holbrook, C. M., Hussey, N. E., Lowerre-Barbieri, S. K., Nguyen, V. M., ... \& Cooke, S. J. 2017. Acoustic telemetry and fisheries management. Ecological Applications, 27(4), 1031-1049.

CSAS-SAR. 2008 Cumberland Sound Greenland halibut (turbot) inshore fishery. Canadian Science Advisory Secretariat, Science Advisory Report 2008/040. 
93 Cvitanovic, C., Marshall, N., Wilson, S., Dobbs, K., \& Hobday, A. 2014. Perceptions of Australian 94 marine protected area managers regarding the role, importance, and achievability of adaptation for 95 managing the risks of climate change. Ecology and Society, 19(4).

96

97 Cvitanovic, C., Hobday, A. J., van Kerkhoff, L., Wilson, S. K., Dobbs, K., \& Marshall, N. A. 2015. 98 Improving knowledge exchange among scientists and decision-makers to facilitate the adaptive 99 governance of marine resources: a review of knowledge and research needs. Ocean \& Coastal 100 Management, 112, 25-35.

101

102 103 104 105 106 107 108 109 110 111 112 113 114 115
Cvitanovic, C., McDonald, J., and Hobday, A. J. 2016. From science to action: Principles for undertaking environmental research that enables knowledge exchange and evidence-based decisionmaking, In Journal of Environmental Management, Volume 183, Part 3, Pages 864-874, ISSN 03014797, https://doi.org/10.1016/j.jenvman.2016.09.038.

Dennard, S.T., MacNeil, M.A., Treble, M., Campana, S., and Fisk, A.T. 2010. Hierarchical analysis of a remote, arctic, artisanal longline fishery. ICES J. Mar. Sci. 67: 41-51

DFO. 2006. Fishery management plan Greenland halibut NAFO subarea 0 2006-2008. Fisheries and Oceans Canada, Central and Arctic Region, Winnipeg, Manitoba

Dick M., Rous A.M., Nguyen V.M., and Cooke S.J. 2016. Necessary but challenging: Multiple disciplinary approaches to solving conservation problems. FACETS 1: 67-82. doi:10.1139/facets-20150003. 
117 Donaldson, M.R., Hinch, S.G., Patterson, D.A., Hills, J., Thomas, J.O., Cooke, S.J., Raby, G.D., 118 Thompson, L.A., Robichaud, D., English, K.K., Farrell, A.P. (2011) The consequences of angling, beach 119 seining, and confinement on the physiology, post-release behaviour and survival of adult sockeye salmon during upriver migration. Fisheries Research 108: 133-141.

Donaldson, M.R., Raby, G.D., Nguyen, V.N., Hinch, S.G., Patterson, D.A., Farrell, A.P., Rudd, M., capture stress: integrating comparative physiology, biotelemetry, and social science to solve a conservation problem. Canadian Journal of Fisheries and Aquatic Sciences 70: 90-100.

Eden, S. 2011. Lessons on the generation of usable science from an assessment of decision support practices. Environ. Sci. Policy 14(1): 11-19. Elsevier Ltd. doi:10.1016/j.envsci.2010.09.011.

English, K. K., Koski, W. R., Sliwinski, C., Blakley A., Cass A., and Woodey J. C. 2005. Migration timing and river survival of late-run Fraser River sockeye salmon estimated using radiotelemetry techniques. Transactions of the American Fisheries Society 134(5): 1342-1365.

Farrell, A. P., Hinch, S. G., Cooke, S. J., Patterson, D. A., Crossin, G. T., Lapointe, M., \& Mathes, M. T. 2008. Pacific salmon in hot water: applying aerobic scope models and biotelemetry to predict the success of spawning migrations. Physiological and Biochemical Zoology, 81(6), 697-708. 
139 Fazey, I., Evely, A.C., Reed, M.S., Stringer, L.C., Kruijsen, J., White, P.C.L., Newsham, A., Jin, L., 140 Cortazzi, M., Phillipson, J., Blackstock, K., Entwistle, N., Sheate, W., Armstrong, F., Blackmore, C., 141 Fazey, J., Ingram, J., Gregson, J., Lowe, P., Morton, S., and Trevitt, C. 2012. Knowledge exchange: a 142 review and research agenda for environmental management. Environ. Conserv. 40(1): 1-18. 143 doi:10.1017/S037689291200029X.

145 Fazey, I., Bunse, L., Msika, J., Pinke, M., Preedy, K., Evely, A. C., ... \& Reed, M. S. 2014. Evaluating 146 knowledge exchange in interdisciplinary and multi-stakeholder research. Global Environmental 147 Change, 25, 204-220.

Fisk et al. CJFAS special Issue (2017). Acoustic Telemetry Observation Systems: challenges encountered and overcome in the Laurentian Great Lakes. Canadian Journal of Fisheries and Aquatic 151 Sciences.

Forester, R. E. 1937. Increasing the survival rate of young sockeye salmon by removing predatory fishes. Pacific Biological Station Progress Report, (32).

Fretwell, M.R. 1989. Homing behavior of adult sockeye salmon in response to a hydroelectric diversion 157 of homewater at Seton Creek. Int. Pac. Salmon Fish. Comm. Bulletin 25. 38pp. 
162 Grubbs, R. D., Musick, J. A., Conrath, C. L., \& Romine, J. G. 2007. Long-term movements, migration, 163 and temporal delineation of a summer nursery for juvenile sandbar sharks in the Chesapeake Bay region. 164 In American Fisheries Society Symposium (Vol. 50, p. 87). American Fisheries Society. 165 HAOC regional report may http://www.habitat.noaa.gov/pdf/Regional-HAPC-Report-May-2016.pdf 167 168 169

Hinch, S.G., Diewert, R.E., Lissimore, T.J., Prince, A.M.J., Healey, M.C., and Henderson, M.A. (1996) Use of electromyogram telemetry to assess difficult passage areas for river migrating adult sockeye salmon. Transactions of the American Fisheries Society 125:253-260.

Hinch, S.G. and Bratty, J.M. (2000) Effects of swim speed and activity pattern on success of adult sockeye salmon migration through an area of difficult passage. Transactions of the American Fisheries Society 129: 604-612.

Hinch, S.G., Gardner, J. (Editors) (2009) Conference on Early Migration and Premature Mortality in 177 Fraser River Late-Run Sockeye Salmon: Proceedings. Vancouver, BC. Published by Pacific Fisheries 178 Resource Conservation Council, Vancouver, BC. 120 pgs. PDF 
184 Hussey, N. E., Kessel, S. T., Aarestrup, K., Cooke, S. J., Cowley, P. D., Fisk, A. T., ... \& Flemming, J. 185 E. M. 2015. Aquatic animal telemetry: a panoramic window into the underwater 186 world. Science, 348(6240), 1255642.

Hussey, N. E., Hedges, K. J., Barkley, A. N., Treble, M. A., Peklova, I., Webber, D. M., ... \& Fisk, A. T. 189

2017. Movements of a deep-water fish: establishing marine fisheries management boundaries in coastal Arctic waters. Ecological Applications, 27(3), 687-704.

Kessel, S. T., Chapman, D. D., Franks, B. R., Gedamke, T., Gruber, S. H., Newman, J. M., ... \& Perkins,

R. G. 2014. Predictable temperature-regulated residency, movement and migration in a large, highly mobile marine predator (Negaprion brevirostris). Marine Ecology Progress Series, 514, 175-190.

Kirchhoff, C.J., Lemos, M.C., and Dessai, S. 2013. Actionable Knowledge for Environmental Decision

Making: Broadening the Usability of Climate Science. doi:10.1146/annurev-environ-022112-112828.

Lapointe, M. F., Cooke, S. J., Hinch, S. G., Farrell, A. P., Jones, S., MacDonald, S., Patterson, D.,

Healey, M. C., and Van Der Kraak, G. 2012. Late-run sockeye salmon in the Fraser River, British Columbia are experiencing early upstream migration and unusually high rates of mortality: what is going on. In Proceedings of the 2003 Georgia Basin/Puget Sound Research Conference, Vancouver,

Larkin PA (1992) Analysis of possible causes of the shortfall in sockeye spawners in the Fraser River: a technical appendix. In Pearse PH, ed., Managing Salmon on the Fraser. Fisheries and Oceans Canada, 207 Vancouver, BC, Canada, pp 1-33. 
209 Macdonald, J. S., Patterson, D. A., Hague, M. J., \& Guthrie, I. C. 2010. Modeling the influence of 210 environmental factors on spawning migration mortality for sockeye salmon fisheries management in the 211 Fraser River, British Columbia. Transactions of the American Fisheries Society, 139(3), 768-782.

MacNeil, M.A., Graham, N.A.J., Cinner , J.E., Loring , P.A., Jennings, S., Dulvy, N.K., Fisk A.T. and

T.R. McClanahan. 2010. Transitional states in marine fisheries: adapting to cope with global change.

215 Philosophical Transactions Royal Society 365: 3753-3763.

Martins, E.G., Hinch, S.G., Patterson, D.A., Hague, M.J., Cooke, S.J., Miller, K.M., Lapointe, M.F.,

English, K.K., Farrell, A.P. (2011) Effects of river temperature and climate warming on stock-specific survival of adult migrating Fraser River sockeye salmon (Oncorhynchus nerka). Global Change Biology 17: 99-114.

Meadow, A.M., Ferguson, D.B., Guido, Z., Horangic, A., Owen, G., and Wall, T. 2015. Moving Toward 223 the Deliberate Co-Production of Climate Science Knowledge. Weather. Clim. Soc.: 150406095212003. doi:10.1175/WCAS-D-14-00050.1.

Miller, K. M., Li, S., Kaukinen, K. H., Ginther, N., Hammill, E., Curtis, J. M. R., Patterson, D. A., 227 Sierocinski, T., Donnison, L., Pavlidis, P., Hinch, S. G., Hruska, K. A., Cooke, S. J., English, K. K. \& 228 Farrell, A. P. 2011. Genomic signatures predict migration and spawning failure in wild Canadian 229 salmon. Science 331, 214-217. 
230 Nel, J.L., Roux, D.J., Driver, A., Hill, L., Maherry, A.C., Snaddon, K., Petersen, C.R., Smith-Adao, 231 L.B., Deventer, H., and Reyers, B. 2016. Knowledge co-production and boundary work to promote 232 implementation of conservation plans. Conserv. Biol. 30(1): 176-188. doi:10.1111/cobi.12560.

NAFO. 2004. Northwest Atlantic Fisheries Organization Scientific Council Reports June 3-17, 2004. Northwest Atlantic Fisheries Organization, Dartmouth, Nova Scotia, Canada. 298 p.

Nguyen, V.M., Young, N., Hinch, H.G., Cooke, S.J. In press. "What is 'usable’ knowledge? Perceived barriers for integrating new knowledge into management of an iconic Canadian fishery" in its current form for publication in the Canadian Journal of Fisheries and Aquatic Sciences. Canadian Journal of Fisheries and Aquatic Sciences. 00:000-000.

Nguyen, V.M., Young, N., and Cooke, S.J. 2017. A roadmap for knowledge exchange and mobilization research in conservation and natural resource management. Conservation Biology. 31:789-798. qualitative study. Canadian Journal of Fisheries and Aquatic Sciences. 00:000-000.

Nguyen, V.M., Young, N., and Cooke, S.J. 2016. A roadmap for knowledge exchange and mobilization research in conservation and natural resource management. Conserv. Biol. 0(0): n/a-n/a.

253 Nguyen, V.M., Raby, G.D., Hinch, S.G., and Cooke, S.J. 2012. Aboriginal fisher perspectives on use of 254 biotelemetry technology to study adult Pacific salmon. Knowl. Manag. Aquat. Ecosyst. (406): 8. । 
255 doi:10.1051/kmae/2012025.

256

257 National Marine Fisheries Service, Proposed HAPC and EFH boundaries, 2016.

258 http://www.habitat.noaa.gov/pdf/Regional-HAPC-Report-May-2016.pdf

259

260 National Marine Fisheries Service, Proposed HAPC and EFH boundaries, 2017, ArcMap shapefiles:

261 http://www.nmfs.noaa.gov/sfa/hms/documents/fmp/am10/index.html

262

263 National Marine Fisheries Service, HAPC 2017

264 http://www.nmfs.noaa.gov/sfa/hms/documents/fmp/am10/final_maps/lemon-adu-fa10-final-508.pdf 265

266 NWMB-NCRI. 2013. Turbot IQ. Nunavut Wildlife Management Board- Nunavut Coastal Resource 267 Inventory, March 2013.

268

269 Nyggard, R. 2015. Fisheries and catches of Greenland halibut stock component in NAFO Division 1A 270 Inshore in 2014. Northwest Atlantic Fisheries Organization Scientific Council meeting, June 2015.

271 NAFO SCR Doc. 15/039

272

273 Ogburn, M.B., Harrison, A.L., Whoriskey, F.G., Cooke, S.J., Mills Flemming, J.E. and Torres, L.G., 274 2017. Addressing Challenges in the Application of Animal Movement Ecology to Aquatic Conservation 275 and Management. Frontiers in Marine Science, 4, p.70.

276

277 Pacific Salmon Treaty (1999) http://www.psc.org/pubs/Treaty/Treaty.pdf 278 
279 Patterson, D.A, Cooke, S.J., Hinch, S.G., Robinson, K., Young, N., Farrell, A.P., and Miller, K. 2016. 280 A perspective on physiological studies supporting the provision of scientific advice for the management 281 of Fraser River sockeye salmon (Oncorhynchus nerka). Conservation Physiology 4(1): cow026 DOI $28210.1093 /$ conphys/cow02. cow026.

Patterson, D.A., Robinson, K.A., Lennox, R.J., Nettles, T.L., Donaldson, L.A., Eliason, E.J., Raby, G.D., Chapman, J.M., Cook, K.V., Donaldson, M.R., Bass, A.L., Drenner, S.M., Reid, A.J., Cooke, S.J., and Hinch, S.G. 2017a. Review and evaluation of fishing-related incidental mortality for Pacific salmon. DFO Canadian Science Advisory Secretariat Research Document 2017/010. ix + 155 p.

Patterson, D.A., Robinson, K.A., Raby, G.D., Bass, A.L., Houtman, R., Hinch, S.G., and Cooke, S.J. 2017b. Guidance to derive and update fishing-related incidental mortality rates for Pacific salmon. DFO Canadian Science Advisory Secretariat Research Document 2017/011. vii + 56 p. 
302 Raby, G.D., Wilson, S.M., Patterson, D.A., Hinch, S.G., Clark, T.D., Farrell, A.P., Cooke, S.J. 2015a. A 303 physiological comparison of three techniques for reviving sockeye salmon exposed to a severe capture 304 stressor during upriver migration. Conservation Physiology 3:doi:10.1093/conphys/cov015.

Raby, G.D., Donaldson, M.R., Hinch, S.G., Clark, T.D., Eliason, E.J., Jeffries, K.M., Cook, K.V.,

Teffer, A., Bass, A.L., Miller, K.M., Patterson, D.A., Farrell, A.P., Cooke, S.J. 2015b. Fishing for effective conservation: context and biotic variation are keys to understanding the survival of Pacific salmon after catch-and-release. Integrative and Comparative Biology 55(4):554-576.

Raby, G.D., Hinch, S.G., Patterson, D.A., Hills, J.A., Thompson, L.A., Cooke, S.J. 2015c. Mechanisms to explain purse seine bycatch mortality of coho salmon. Ecological Applications 25(7):1757-1775.

Reyier, E. A., Franks, B. R., Chapman, D. D., Scheidt, D. M., Stolen, E. D., \& Gruber, S. H. 2014. South Atlantic. PloS one, 9(2), e88470. Board of Canada, 21(5), 905-931. panmixia in Greenland halibut (Reinhardtius hippoglossoides) in the Northwest Atlantic. Canadian Journal of Fisheries and Aquatic Sciences, 71(5), 763-774. 
324 temperature on sockeye salmon in a simulated capture-and-release experiment. Conservation Physiology $32510.1093 /$ conphys/cot015.

327 Robinson, K.A., Hinch, S.G., Raby, G.D., Donaldson, M.R., Robichaud, D., Patterson, D.A., Cooke, S.J. 328 (2015) Influence of post-capture ventilation assistance on migration success of adult sockeye salmon 329 following capture and release. Transactions of the American Fisheries Society 144:693-704.

Shiffman, D. S., \& Hammerschlag, N. 2014. An Assessment of the Scale, Practices, and Conservation

Stephenson, T.D., Treble, M.A., Mathias, J.A., Pike, D.G. 1997. Experimental tagging of Greenland halibut () in Cumberland Sound, Baffin Island, during winter fishery, May 1997. Northwest Atlantic

Treble, M.A. 2003. Results of a Greenland halibut (Reinhardtius hippoglossoides) tagging project in 345 Scientific Council meeting, June 2003. NAFO SCR Doc. 03/41 
347 Vis, M. L., Carr, S. M., Bowering, W. R., \& Davidson, W. S. 1997. Greenland halibut (Reinhardtius

348 hippoglossoides) in the North Atlantic are genetically homogeneous. Canadian Journal of Fisheries and 349 Aquatic Sciences, 54(8), 1813-1821.

350

351 Tom Wappel, M.P., Chair, Here we go again... or the 2004 Fraser DFO RESPONSE

352 River Salmon Fishery - Report of the Standing Committee on Fisheries and Oceans, March 2005

353

354 Williams, B. (2005) 2004 Southern salmon fishery post-season review, part 1. Fraser River sockeye 355 report. http://waves-vagues.dfo-mpo.gc.ca/Library/314601.pdf

356 Woodey, J. C. 1987. In-season management of Fraser River sockeye salmon (Oncorhynchus nerka): 357 meeting multiple objectives. Sockeye salmon, 367-374.

358 Woodley, JC. 1987. In-season management of Fraser River sockeye salmon (Oncorhynchus nerka): 359 meeting multiple objectives. In Sockeye salmon (Oncorhynchus nerka) population biology and future 360 management. Ed. Smith, HD, Margolis, L, and Wood, CC. Canadian Special Publiscations in Fisheries 361 and Aquatic Sciences. 96. Pp. 367-374.

363 Young, J.L., Hinch, S.G., Cooke, S.J., Crossin, G.T., Patterson, D.A., Farrell, A.P., Kraak, G.V.D.,

364 Lotto, A.G., Lister, A., Healey, M.C. and English, K.K., 2006. Physiological and energetic correlates of 365 en route mortality for abnormally early migrating adult sockeye salmon (Oncorhynchus nerka) in the 366 Thompson River, British Columbia. Canadian Journal of Fisheries and Aquatic Sciences, 63(5):10673671077. 
369 Young, N, Gingras, I, Nguyen, VM, Cooke, SJ, Hinch, SG. 2013. Mobilizing new science into 370 management practice: The challenge of biotelemetry for fisheries management, a cast study of Canada's 371 Fraser River.

372

373 Young, N., Corriveau, M., Nguyen, V.M., Cooke, S.J. and Hinch, S.G. 2016. How do potential 374 knowledge users evaluate new claims about a contested resource? Problems of power and politics in 375 knowledge exchange and mobilization. Journal of Environmental Management. 184: 380-388 376 377 378 379 380 381 382 383 384 385 386 387 388 389 390 